\title{
Interdisciplinary paleovegetation study in the Fernando de Noronha Island (Pernambuco State), northeastern Brazil
}

\author{
LUIZ C.R. PESSENDA ${ }^{1}$, SUSY E.M. GOUVEIA ${ }^{1}$, MARIE-PIERRE LEDRU ${ }^{2}$, RAMON ARAVENA ${ }^{3}$, \\ FRESIA S. RICARDI-BRANCO ${ }^{4}$, JOSÉ A. BENDASSOLLI ${ }^{5}$, ADAUTO DE S. RIBEIRO ${ }^{6}$, \\ SORAYA E.M.G. SAIA ${ }^{1}$, ABDELFETTAH SIFEDDINE ${ }^{2}$, ELDEMAR DE A. MENOR ${ }^{7}$, \\ SÔNIA M.B. DE OLIVEIRA ${ }^{8}$, RENATO C. CORDEIRO ${ }^{9}$, ÂNGELA M. DE M. FREITAS $^{10}$, \\ RENÉ BOULET $^{8}$, HELOISA F. FILIZOLA ${ }^{11}$ \\ ${ }^{1}$ Laboratório de Carbono 14, CENA/USP, Av. Centenário, 303, Caixa Postal 96, 13400-970 Piracicaba, SP, Brasil \\ ${ }^{2}$ Institut de Recherche pour le Développement, 32 avenue Henri-Varagnat, F-93143 Bondy Cedex, France \\ ${ }^{3}$ Department of Earth and Environmental Sciences, University of Waterloo, 200 University Avenue \\ Waterloo, Ontario, Canada N2L 3G1 \\ ${ }^{4}$ Departamento de Geologia e Recursos Naturais, Instituto de Geociências, UNICAMP \\ Caixa Postal 6152, 13083-970 Campinas, SP, Brasil \\ ${ }^{5}$ Laboratório de Isótopos Estáveis, CENA/USP, Av. Centenário, 303, Caixa Postal 96, 13400-970 Piracicaba, SP, Brasil \\ ${ }^{6}$ Universidade Federal de Sergipe, Centro de Ciências Biológicas e da Saúde, São Cristóvão, 49100-000 Aracaju, SE, Brasil \\ ${ }^{7}$ Universidade Federal de Pernambuco, Departamento de Geologia, Avenida Ramos s/n, 50749-530 Recife, PE, Brasil \\ ${ }^{8}$ Instituto de Geociências, USP, Rua do Lago, 562, 05508-080 São Paulo, SP, Brasil \\ ${ }^{9}$ Universidade Federal Fluminense, Departamento de Geoquímica, Morro do Valonguinho \\ Outeiro São João Batista, 24020-007 Niterói, RJ, Brasil \\ ${ }^{10}$ Universidade Federal Rural de Pernambuco, Rua Dom Manoel de Medeiros s/n, Dois Irmãos, 52171-900 Recife, PE, Brasil \\ ${ }^{11}$ Embrapa Meio Ambiente, Rodovia SP 340, km 127,5, Caixa Postal 69, 13820-000 Jaguariúna, SP, Brasil
}

Manuscript received on December 3, 2007; accepted for publication on April 4, 2008;

presented by KENITIRO SUGUIO*

\begin{abstract}
The aim of this research was to reconstruct vegetation changes (with climate inferences) that occurred during the Holocene in the Fernando de Noronha Island, Pernambuco State, northeastern Brazil. The research approach included the use of geochemical (mineralogy, elemental), carbon isotopes $\left(\delta^{13} \mathrm{C},{ }^{14} \mathrm{C}\right)$ and pollen analyses in soil organic matter (SOM) and sediments collected in Lagoa da Viração and Manguezal do Sueste. The carbon isotopes data of SOM indicated that there was no significant vegetation changes during the last $7400 \mathrm{BP}$, suggesting that the climate was not the determinant factor for the vegetation dynamics. The pollen analysis of the sediment of a core collected in the Lagoa da Viração showed the absence of Quaternary material in the period between 720 BP and 90 BP. The mineralogical analysis of deeper layer showed the presence of diopside indicating this material was developed "in situ". Only in the shallow part of the core were found pollen of similar plant species of the modern vegetation. The geochemistry and isotope results, in association with the sediment type and pollen analyses of sediment samples of Manguezal do Sueste, indicated variations in the vegetation and in its location since the middle Holocene. Such variations can be associated with climatic events and sea level oscillations and also with anthropogenic events considering the last five hundred years.
\end{abstract}

Key words: pollen, carbon isotopes, paleovegetation, Fernando de Noronha, Holocene.

*Member Academia Brasileira de Ciências Correspondence to: Luiz Carlos Ruiz Pessenda

E-mail: pessenda@cena.usp.br

\section{INTRODUCTION}

Studies of paleoenvironmental changes are rare in northeastern Brazil, probably because of the scarcity of sta- 
ble and perennial lakes and the aridity of the climate. However, the few studies that were carried out in continental areas in this region have shown important changes in vegetation and climate during the late Quaternary. The most common research tools used in these studies include pollen, carbon isotopes and geochemical analyses (De Oliveira et al. 1999, Ledru et al. 2001, Sifedddine et al. 2003, Pessenda et al. 2004, 2005a, b). Sometimes such climatic variations were also linked with sea level dynamics (Suguio et al. 1985), as observed in the studies on emerged shorelines and superbly preserved coastal deposits along the Rio Grande do Norte State (Bezerra et al. 2003).

This paper describes a study aiming to reconstruct the vegetation and climate changes that eventually occurred during the Holocene in Fernando de Noronha Island, Pernambuco State, northeastern Brazil. The paleoenviromental changes were reconstructed based on pollen (sediments only), geochemical and isotope analysis in soils collected in various locations representative of the different vegetation communities and sediments collected in a lake (Lagoa da Viração) and in a mangrove (Manguezal do Sueste).

\section{STUDY AREA}

The Archipelago of Fernando de Noronha is formed by 21 islands and islets, with a total area of 11,270 ha, being Fernando de Noronha the main island (IBAMA 2005) (Fig. 1). In the Table I are showed the sampling points and respective geographic coordinates.

The climate of the area is tropical (Awi of Köppen classification system) influenced by the Atlantic Ocean. The annual average temperature is around $25^{\circ} \mathrm{C}$ and the total annual precipitation is around $1400 \mathrm{~mm}$ with great inter annual variability. There are two seasons wellmarked, being the humid period from March to July and drier from August to January. In relation to the relative air humidity, there is great uniformity during the whole year, with values oscillating around $85 \%$ in the rainy and $81 \%$ in the dry period (M. Batistella, unpublished data).

The flora, characteristic of island environments is poor in species. This pattern is caused by the isolation of the near continent due to the winds and currents dynamics, relative geomorphologic homogeneity and semi-arid climate (M. Batistella, unpublished data). The coloniza- tion of the vegetation probably begun in the Pleistocene, since the volcanism that created the archipelago would have finished about 1,8 Ma approximately (Teixeira et al. 2003).

The Lagoa da Viração, enclosed for native vegetation and covered by aquatic plant (Pistia stratiotes) is located between the Praia do Leão and Ponta da Sapata about $20 \mathrm{~m}$ above the mean sea level (Fig. 1, Table I). The water column is around $1.50 \mathrm{~m}$ in the central part of the lake.

The plain is limited by a cliff of approximately $100 \mathrm{~m}$, formed by basalt sills intercalated by layers of piroclastic materials (ashes and volcanic blocks), practically establishing a complete isolation of the area. The dense vegetation and the geological setting are responsible for a natural geomorphologic protection and preservation of the lake. The terrestrial input is reduced, due to the predominance of a diffuse pluvial drainage system that permeates through a relatively dense surrounding vegetation (A.S. Moraes, unpublished data).

An important climatic factor that influences the vegetation covering of the Archipelago is the constant wind. The trade winds with direction ESE reach mainly the windward face, where it is located the Sueste bay (Fig. 1) and Manguezal do Sueste (Table I).

The vegetation of Manguezal do Sueste is only composed by Laguncularia sp. and it represents one of the only places of the occurrence of this species in oceanic islands of the South Atlantic Ocean. The trees are $7 \mathrm{~m}$ tall on average. During the Holocene they occupied a larger area, being considered today as a relic of earlier periods (M. Batistella, unpublished data).

Concerning the hydrology, the Maceió River is the main water body of the island that was feeding before the Manguezal do Sueste. At present, the river ends in the Xaréu reservoir. The remaining bodies of water are of moderate dimensions, being all intermittent ones, drying quickly at the end of the rainy season.

\section{MATERIALS AND METHODS}

\section{VEGETATION}

The structure of the vegetation was determined based on the Brower and Zar (1984) method that consists of measuring the dispersion of the current population of the trees with the trunk whose CAP (circumference on the 


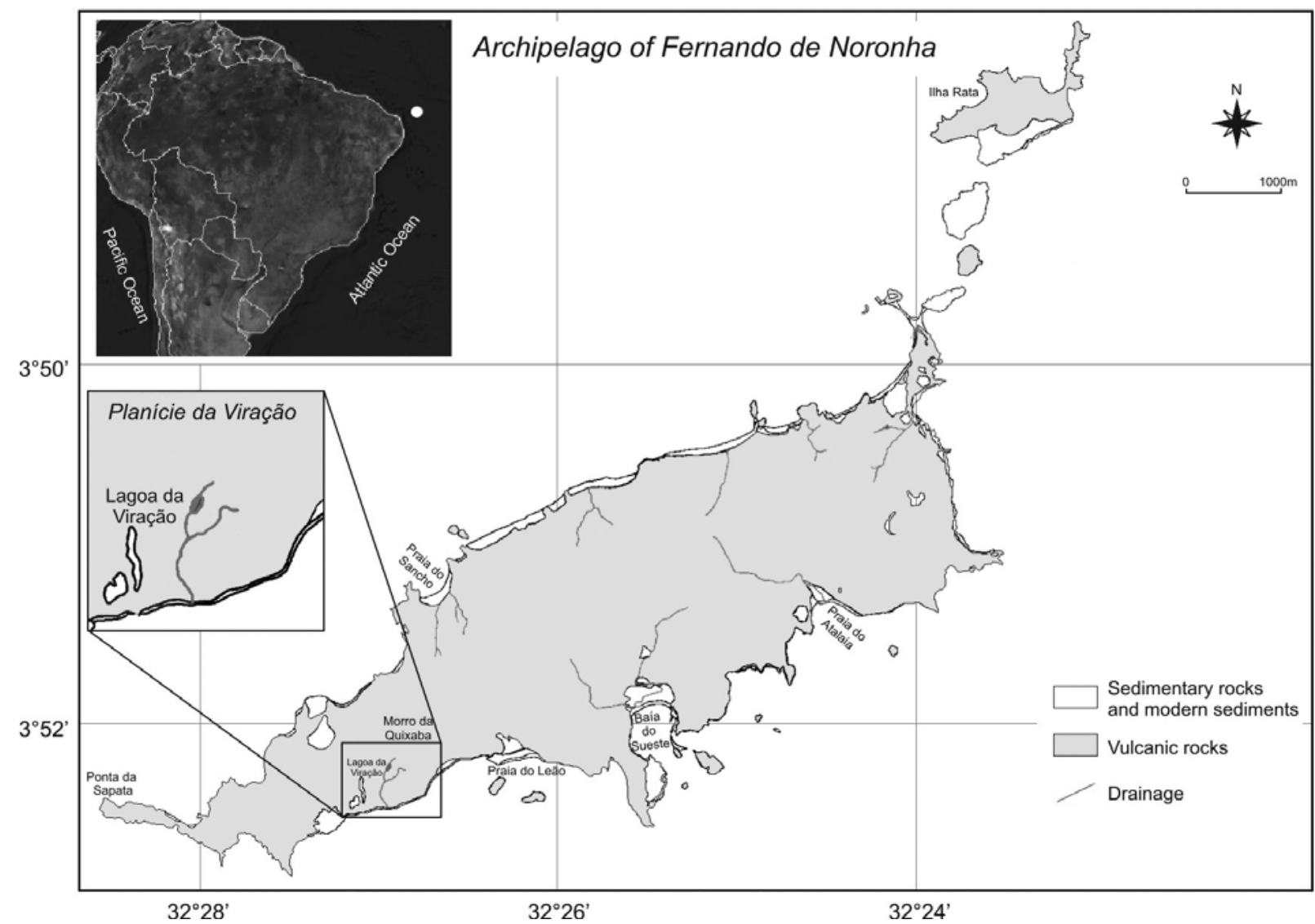

Fig. 1 - Archipelago of Fernando de Noronha showing the location of Lagoa da Viração (modified from Ulbrich et al. 2004). The Manguezal do Sueste is located in the Baía do Sueste. The geographic coordinates of soil sampling points are shown in the Table I.

height of the chest) is larger than $20 \mathrm{~cm}$. Four structural parameters were analyzed for the characterization of the vegetation: CAP, height of the fork, total height of the trees and the distance among the closest trees. A botanical identification of the dominant species was also made around the Lagoa da Viração.

\section{SoILS}

The soil is shallow with great amount of stones on the surface soil and is classified as Haplic Cambisol. The soil sampling was performed in a trench and by a hand auger. Information about the sampling sites is found in Table I.

For the ${ }^{14} \mathrm{C}$ dating of the soil organic matter (SOM), samples of approximately $5 \mathrm{~kg}$ were collected each $10 \mathrm{~cm}$ from a $300 \mathrm{~cm}$ deep trench. Soil samples for isotopic determination $\left({ }^{13} \mathrm{C}\right)$ were collected by drilling, dried at $60^{\circ} \mathrm{C}$ up to constant weight and sieved to $0.210 \mathrm{~mm}$ before analyses.
Grain size analyses were carried out at the Soil Science Department of the Escola Superior de Agricultura "Luiz de Queiroz" (Piracicaba, Brazil) using the densimeter method (Kiehl 1979) and the results are reported as clay percentage.

The mineralogical composition of the soil from the trench at Morro da Quixaba was qualitatively determined by X-ray diffraction. An estimate of the relative amounts of the present minerals was made by comparison of the height of the characteristic picks of the minerals. The equipment used was a Siemmens D5000 of the X-Rays Diffraction Laboratory of the Geosciences Institute, University of São Paulo (São Paulo State).

The total organic $\mathrm{C}$ and ${ }^{13} \mathrm{C}$ analyses were carried out at the Stable Isotopes Laboratory of CENA (Piracicaba, Brazil). The results are expressed in percentage of dry weight and " $\delta$ " units (\%०), respectively. The $\delta$ values are reported in relation to the international standard 
TABLE I

Study sites in Fernando de Noronha.

\begin{tabular}{|c|c|c|c|c|}
\hline $\begin{array}{l}\text { Sampling } \\
\text { points }\end{array}$ & Region & $\begin{array}{c}\text { Geografic } \\
\text { coordinates }\end{array}$ & $\begin{array}{l}\text { Altitude } \\
\text { (m) }\end{array}$ & $\begin{array}{c}\text { Collected } \\
\text { material }\end{array}$ \\
\hline Trench & $\begin{array}{c}\text { Morro } \\
\text { da Quixaba }\end{array}$ & $\begin{array}{c}3^{\circ} 52^{\prime} 01.0 ’ \mathrm{~S} \\
32^{\circ} 26 ’ 57.4 \text { 'W }\end{array}$ & 170 & $\begin{array}{c}\text { Soil } \\
\text { and plant }\end{array}$ \\
\hline $\mathrm{LV}$ & $\begin{array}{c}\text { Lagoa } \\
\text { da Viração }\end{array}$ & $\begin{array}{c}3^{\circ} 52^{\prime} 13.5 ’ \mathrm{~S} \\
32^{\circ} 26^{\prime} 53.5 ’ \mathrm{~W}\end{array}$ & 23 & $\begin{array}{l}\text { Sediment } \\
\text { and plant }\end{array}$ \\
\hline Sancho (1) & & $\begin{array}{l}3^{\circ} 51^{\prime} 38.8^{\prime \prime S} \\
32^{\circ} 27^{\prime} 8.3^{\prime \prime} \mathrm{W}\end{array}$ & $60-70$ & Soil \\
\hline Sancho (2) & $\begin{array}{l}40 \text { m upstream } \\
\text { of Sancho (1) }\end{array}$ & $*$ & $60-70$ & Soil \\
\hline Sancho (3) & $\begin{array}{c}30 \text { m downstream } \\
\text { of Sancho (1) }\end{array}$ & * & $60-70$ & Soil \\
\hline Ilha Rata & & $\begin{array}{c}3^{\circ} 49 ' 10.2 ” \mathrm{~S} \\
32^{\circ} 233^{\prime} 31.7 ’ \mathrm{~W}\end{array}$ & 30 & Soil \\
\hline Atalaia & & $\begin{array}{c}3^{\circ} 51 ' 32.4 ” S \\
32^{\circ} 24{ }^{\prime} 44.7 ’ \mathrm{~W}\end{array}$ & Sea level & Soil \\
\hline Praia do Leão & & $*$ & Sea level & Soil \\
\hline MPO & $\begin{array}{c}\text { Mata da } \\
\text { Ponta Oeste }\end{array}$ & $\begin{array}{c}3^{\circ} 52 ' 33.5 ’ \mathrm{~S} \\
31^{\circ} 27^{\prime} 22.8^{\prime} \mathrm{W}\end{array}$ & 100 & Soil \\
\hline $\mathrm{SE}$ & $\begin{array}{l}\text { Mangue do } \\
\text { Sueste }\end{array}$ & $\begin{array}{c}3^{\circ} 51 ' 56.4 ’ \mathrm{~S} \\
32^{\circ} 25^{\prime} 31.8 ’ \mathrm{~W}\end{array}$ & Sea level & Sediment \\
\hline
\end{tabular}

PDB, with analytical precision of $\pm 0.2 \%$ (Pessenda et al. 2004, 2005a).

For ${ }^{14} \mathrm{C}$ dating, the soil humin fraction was isolated by physical and chemical pre-treatments (Pessenda et al. 1996) and the ${ }^{14} \mathrm{C}$ dating carried out at the Isotrace Laboratory in Toronto, Canada, through AMS (Accelerator Mass Spectrometry). The ${ }^{14} \mathrm{C}$ ages are presented in years BP (before present) normalized to a $\delta^{13} \mathrm{C}$ of $-25 \%$ PDB and in cal yr BP (Stuiver et al. 1998). The

${ }^{14} \mathrm{C}$ dating in years $\mathrm{BP}$ will be use for the presentation and discussion of the results.

\section{SEdiment SAMPLES}

A $72 \mathrm{~cm}$ sediment core was sampled in the central region of Lagoa da Viração and a $220 \mathrm{~cm}$ sediment core in the Manguezal do Sueste using a vibracorer (Martin and Flexor 1989) and a 3-inch diameter aluminum tube. After opening and macroscopic description of the sedimentary deposits at the Geochemistry Laboratory of Federal Fluminense University (Niterói, Brazil), samples were collected in plastic cubes of $2 \mathrm{~cm}^{3}$ in $2 \mathrm{~cm}$ intervals for pollen, geochemistry and mineralogical analyses.

The chemical treatment of the samples followed the methodology of Faegri and Iversen (1989), with identification using a microscope Carl Zeiss Axioskop 40 and comparison with reference pollen atlas and with pollen collection done for this study. From fifteen samples of Manguezal do Sueste, were studied those corresponding to the striped intervals in the Table II, since they presented larger possibility to contain palinomorphs after the chemical preparation.

About $100 \mathrm{mg}$ of chemically pre-treated ( $\mathrm{HCl} 4 \%)$ sediments samples were sent to the Environmental Isotopes Laboratory of the University of Waterloo, Canada, for elementary $(\mathrm{C}, \mathrm{N})$ and isotopic $\left(\delta^{13} \mathrm{C}\right)$ determinations that were performed in a Carlo Erba analyzer coupled to a mass spectrometer Optima. The results are expressed in percentage of dry weight and in the relative " $\delta$ " unit $(\% \circ)$, determined in relation to the international standard PDB for ${ }^{13} \mathrm{C}$.

For radiocarbon analyses, sediments samples were subjected to physical treatment (removal of vegetable 
TABLE II

Studied intervals $\times$ number of pollen found.

\begin{tabular}{c|c}
\hline Depth $(\mathrm{cm})$ & $\begin{array}{c}\text { Number of pollen } \\
\text { found }\end{array}$ \\
\hline $10-12$ & 363 \\
\hline $22-24$ & 360 \\
\hline $32-34$ & 134 \\
\hline $44-46$ & 144 \\
\hline $122-124$ & 8 \\
\hline $126-128$ & 162 \\
\hline $130-132$ & 69 \\
\hline $186-188$ & 105 \\
\hline $191-192$ & 318 \\
\hline $196-198$ & 204 \\
\hline
\end{tabular}

remains, etc.) and treated later with $\mathrm{HCl} 4 \%$ for $5 \mathrm{~h}$ at $80^{\circ} \mathrm{C}$. After successive washes (up to $\mathrm{pH} 5$ ) with deionised water and drying to $60^{\circ} \mathrm{C}$ for $48 \mathrm{~h}$, the samples were combusted and the purified $\mathrm{CO}_{2}$ sent to the Isotrace Laboratory, University of Toronto, Canada, for AMS dating.

The mineralogical composition of the sediments was determined at the X-Ray Diffraction Laboratory at the Institute of Geoscience of USP (São Paulo, Brazil) using the equipment Siemmens D 5000.

\section{RESULTS AND DISCUSSIONS}

\section{VEGETATION}

Four physiognomic units of vegetation were observed in the area of Lagoa da Viração: (i) cliff vegetation, which was defined by the distribution of windward species, with the dominance of $\mathrm{C}_{4}$ grass Paspalum paniculatum - Poaceae; (ii) coastal area vegetation represented by the presence of insular Cactus, (iii) interior areas vegetation characterized by the presence of species arborealshrubs ( 3 to $5 \mathrm{~m}$ of height) and a thin herbaceous substratum with little regeneration and Cactus dominance and (iv) quite altered forested areas, formed by tree strata. The lake is covered completely by Pistia stratiodes (Araceae) giving its green coloration, while in their margins the vegetation reaches up to $25 \mathrm{~m}$ height. The difficult access to the area seems to preserve the forest formations (Gouveia et al. 2005).

The riparian vegetation of the lake extend up to $\sim 40 \mathrm{~m}$ of their margins, presenting an arboreal gradi- ent with dossal, sub-dossal and thin herbaceous stratum with little regeneration. The dossal was characterized by the dominance of Tabebuia roseoalba (Bignoniaceae), representing $53.6 \%$ of sampled trees in 16 quadrants of $25 \mathrm{~m}^{2}$. The Erythrina velutina (Fabaceae) represents $17.9 \%$ of the trees and the abundance in the area was of $22.3 \%$, while the Capparis cynophallophora (Capparaceae), with $14.3 \%$ of the total of the dossal trees, occurred in $18.7 \%$ of the quadrants. The arboreal stratum presented the medium height of $12.5 \pm 5.0 \mathrm{~m}$, with variance of $24.5 \mathrm{~m}$ for the trees (Gouveia et al. 2005).

In the herbaceous-shrub stratum of the forest it was observed the predominance of Capparis leafy (frondosa) - Capparaceae (87.5\%), while the frequency of C. cynophallophora was estimated in $25 \%$. These two species are present in all forests of the island and now they serve as forage for the cattle. The presence of Pistia stratiodes in $18.8 \%$ of the sampled area indicates that the level of the water is variable, maintaining the quite humid margins, making possible the survival of that species. The arboreal species Erythrina velutina and Tabebuia roseoalba presented regeneration in $31.2 \%$ and $12.5 \%$ of the sampled area, indicating an important dispersion of these species (Gouveia et al. 2005).

Laguncularia was the only tree of the Manguezal do Sueste. In the immediate surroundings the following trees have been identified: Senna (Caesalpiniaceae), Capparis cynophallophora (Capparidaceae), Sapium (Euphorbiaceae), Canavalia (Fabaceae), Leucaena (Mimosaceae) and harbaceous plants Mitra (Rubiaceae), Estactafeta (Verbenaceae), Desmodium (Fabaceae), Amaranthaceae and some ruderals of the family of the Euphorbiaceae and Turneraceae (Pessenda et al. 2005b).

\section{SoILS}

The soils presented clay content higher than $50 \%$ and the general tendency is a decreasing of the carbon concentration with increasing depth, varying from 1 to $3 \%$ in the surface to values around $0.3 \%$ at about $300 \mathrm{~cm}$ (Gouveia et al. 2005).

The mineralogical analysis indicated that the samples up to $290 \mathrm{~cm}$ present material well weathered, practically deprived of primary minerals. Just some opaque as magnetite, ilmenite and pseudobrookite were observed. Smectite and kaolinite were found in the basal part of 
the soil profile and at the surface the smectite disappears, probably transformed in kaolinite (Oliveira et al. 2005).

The ${ }^{14} \mathrm{C}$ dating of soil samples showed ages of $7380 \pm 80 \mathrm{BP}$ at the $220-210 \mathrm{~cm}$ depth interval and $5730 \pm 70 \mathrm{BP}$ at $130-120 \mathrm{~cm}$ depth interval (Fig. 2 and Table III). Similar ${ }^{14} \mathrm{C}$ dates were obtained for the humin fraction at similar soil depths in distinct soils and locations in Brazil (Gouveia et al. 2002, Pessenda et al. 2001, 2004, 2005a).

The isotopic $\left(\delta^{13} \mathrm{C}\right)$ values of SOM of the shallow layers characterized the vegetation cover of each study site (Fig. 2). In the locations, Sancho, Ilha Rata and MPO and in the trench at Morro da Quixaba (Table I), the data between $-25 \%$ and $-25.8 \%$ indicate the presence of an open arboreal vegetation dominated by $\mathrm{C}_{3}$ plant type, while in the Praia do Leão and Atalaia, the $\delta^{13} \mathrm{C}$ values of $\sim-19 \%$ indicates a mixture of $\mathrm{C}_{4}$ and $\mathrm{C}_{3}$ plants. No significant $\delta^{13} \mathrm{C}$ changes were observed with depth in the locations currently colonized by $\mathrm{C}_{3}$ plants, excepting at sites Sancho 3 and Ilha Rata where enriched values as $-23 \%$ were observed in part of their ${ }^{13} \mathrm{C}$ record (Fig. 2). This pattern suggests that $\mathrm{C}_{4}$ plants started to colonize these locations probably during a drier period. The sites represented by a mixture of $\mathrm{C}_{3}$ and $\mathrm{C}_{4}$ plants, with the exception of a value of $-16.5 \%$ in the deepest sample at Atalaia site, do not show also significant changes with depth (Fig. 2) indicating the vegetation communities have not changed in the period of the last 300 years represented by the record.

Despite that significant vegetation changes have not been observed in the Fernando de Noronha archipelago, evidence for climate changes in the northeastern region of Brazil have been documented in studies carried out in continental areas. In a peat bog in the Icatu River valley in the semi-arid region of Bahia State, it was documented vegetation and climate changes during the last $11 \mathrm{ka} B P$ (De Oliveira et al. 1999), with a humid period during the early Holocene, becoming progressively drier during the Holocene. In the northernmost region, the vegetation is scarce and open at the beginning of the Holocene, changing progressively toward a woody savanna (Behling et al. 2000, Ledru et al. 2001). At Lagoa do Caçó, Maranhão State, a dry period until 7000 cal BP (c. 6 ka BP) was observed despite the gradual increase in lake water level inferred from sedimentological and geochemical analysis (Sifeddine et al. 2003). In the same region, Pessenda et al. (2005a) attested that carbon isotopes were good indicators for regional paleonvironmental reconstructions and show a similar overall pattern of changes to the pollen records, as a drier early/mid Holocene period than the late Pleistocene period, and a consequent woody savanna vegetation expansion in the region.

\section{Lacustrine Material of Lagoa da Viração}

The ${ }^{14} \mathrm{C}$ dating indicated that the core material represents the last 750 years. The ${ }^{14} \mathrm{C}$ dates obtained were $720 \pm 60 \mathrm{BP}$ for layer $72-70 \mathrm{~cm}, 390 \pm 50 \mathrm{BP}$ for $52-50 \mathrm{~cm}$ and $90 \pm 50 \mathrm{BP}$ for $32-30 \mathrm{~cm}$ (Fig. 3 and Table III).

The pollen content generally reflect the local vegetation. The main tree species that grow in this area, Capparis and Erythrina, are represented on the diagram (Fig. 4). However, Bignoniaceae Tabebuia roseoalba very abundant as a plant (53\%) is never represented in the pollen spectra. One explanation could be the entomophilous dispersion of the pollen grains but the same characteristic is also observed for Capparis and Erythrina which are identified in the pollen content. At the moment we do not have any argument to explain this result.

Based on differences in pollen spectra, two pollen zones could be distinguished (Fig. 4). One at the bottom of the record, between 60 and $28 \mathrm{~cm}$ depth and the second one at the top of the record, between 18 and $0 \mathrm{~cm}$ depth.

The environmental change that occurred between 30 and $18 \mathrm{~cm}$ depth is characterized by the disparition of the damaged pollen grains that are very abundant in the first pollen zone. In this zone an assemblage that includes Rubia, Chenopodiaceae, Gomphrena and Cyperaceae is observed. Chenopodiaceae and Gomphrena are halophylous taxa and grow as small herbs on the edges of temporal lakes. This is in agreement with the high frequencies of damaged pollen grains which may be due to an oxidation of the deposited pollen grains during the dry season when the lake evaporated. The upper zone is richer in identified taxa than the previous one and may correspond to the introduction of Pistia which contributed to maintain a permanent lake and regular 


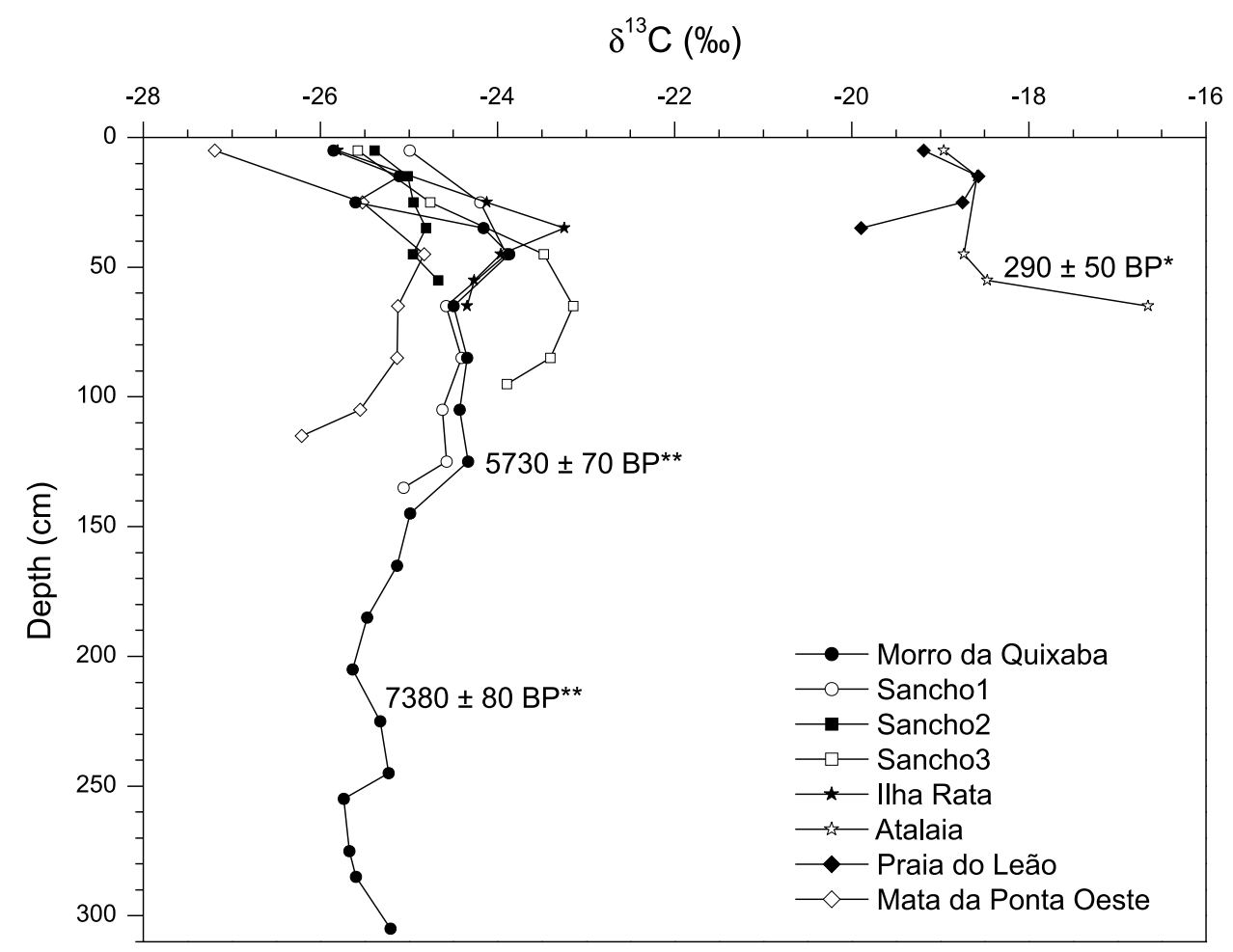

Fig. 2 - Isotopic values $\left(\delta^{13} \mathrm{C}\right)$ in relation to soil depth collected in distinct locations at Fernando de Noronha and respective ${ }^{14} \mathrm{C}$ ages of charcoal fragments $(*)$ and humin fraction $(* *)$.

TABLE III

${ }^{14} \mathrm{C}$ dating of charcoal fragment, soil organic matter and sediment samples from Lagoa da Viração e Manguezal do Sueste.

\begin{tabular}{|c|c|c|c|c|}
\hline Sample & Location & Depth (cm) & $\begin{array}{c}{ }^{14} \mathrm{C} \text { Age } \\
\text { (BP) }\end{array}$ & $\begin{array}{l}{ }^{14} \mathrm{C} \text { Age } \\
\text { (cal BP) }\end{array}$ \\
\hline Charcoal fragment & Atalaia & $50-60$ & $290 \pm 50$ & $280-490$ \\
\hline \multirow{2}{*}{ SOM (Humin) } & \multirow{2}{*}{$\begin{array}{c}\text { Morro } \\
\text { da Quixaba }\end{array}$} & $120-130$ & $5730 \pm 70$ & $6390-6680$ \\
\hline & & $210-220$ & $7380 \pm 80$ & $8030-8360$ \\
\hline \multirow{3}{*}{ Sediment } & \multirow{3}{*}{$\begin{array}{c}\text { Lagoa } \\
\text { da Viração }\end{array}$} & $30-32$ & $90 \pm 50$ & $10-150$ \\
\hline & & $50-52$ & $390 \pm 50$ & $420-510$ \\
\hline & & $70-72$ & $720 \pm 60$ & $620-740$ \\
\hline \multirow{6}{*}{ Sediment } & \multirow{6}{*}{$\begin{array}{c}\text { Manguezal } \\
\text { do Sueste }\end{array}$} & 28 & Modern & $1958^{*}$ \\
\hline & & 46 & Modern & 1959* \\
\hline & & $132-134$ & $440 \pm 50$ & $430-540$ \\
\hline & & $138-140$ & $710 \pm 50$ & $630-730$ \\
\hline & & 191-192 & $1930 \pm 50$ & $1770-1990$ \\
\hline & & $214-216$ & $4240 \pm 60$ & $4780-4970$ \\
\hline
\end{tabular}

*cal AD 

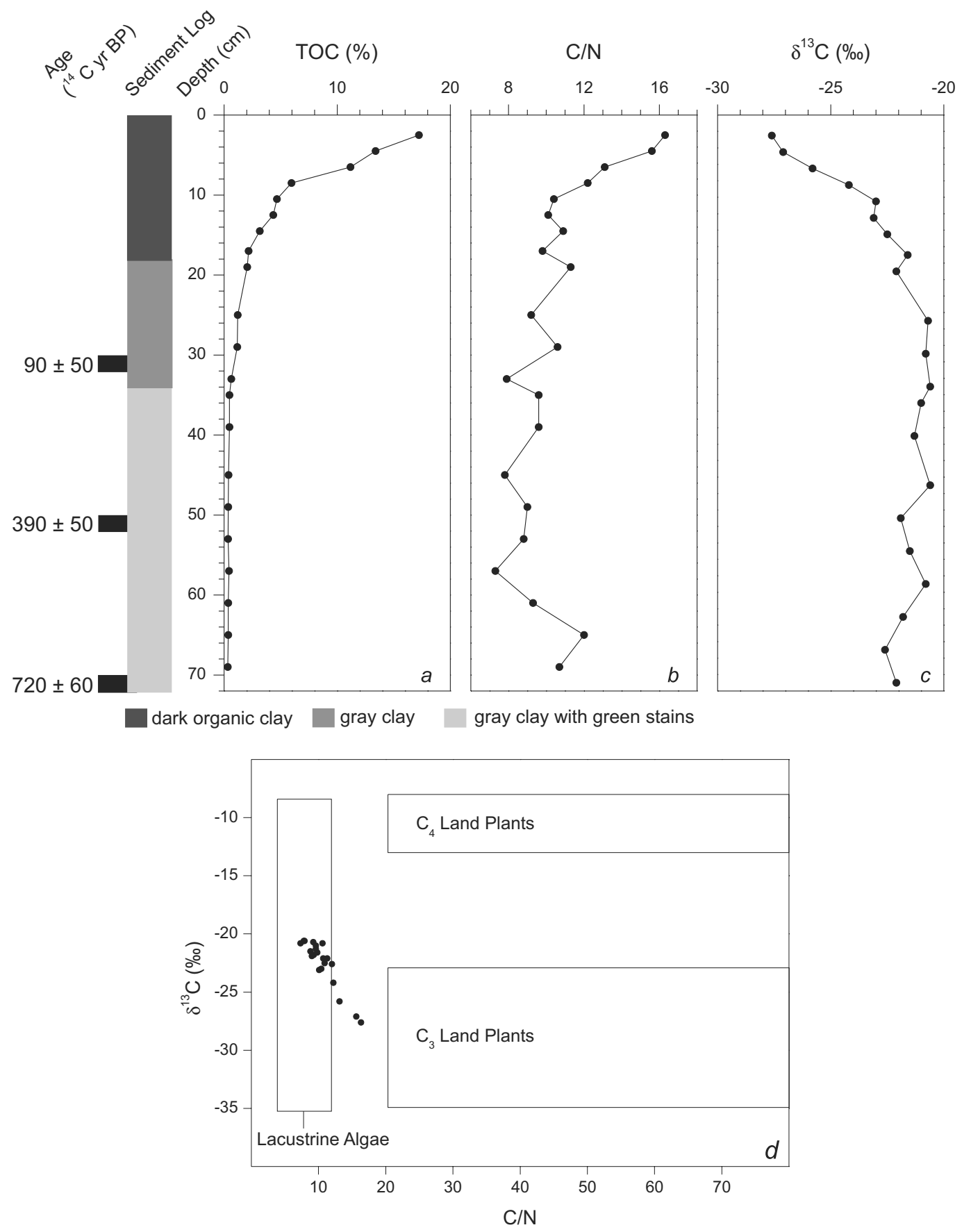

Fig. 3 - Sediment $\log ,{ }^{14} \mathrm{C}$ dating, (a) total organic carbon, (b) $\mathrm{C} / \mathrm{N}$ ratio, (c) $\delta^{13} \mathrm{C}$ and (d) $\mathrm{C} / \mathrm{N} \times \delta^{13} \mathrm{C}$ diagram (modified from Sifeddine et al. 2004) of sediment samples of Lagoa da Viração.

sediment deposition with capacity for a good pollen preservation. The pollen of the Pontederiaceae Pistia is generally destroyed by the chemical treatment when separating pollen from the sediment and therefore could not be observed in this record.
The mineralogical analysis of the lake samples indicated the presence of diopside (primary mineral) and the smectite is the phase broadly dominant, accompanied of hematite. The presence of diopside, the abundance of other primary phases and significant differences in re- 


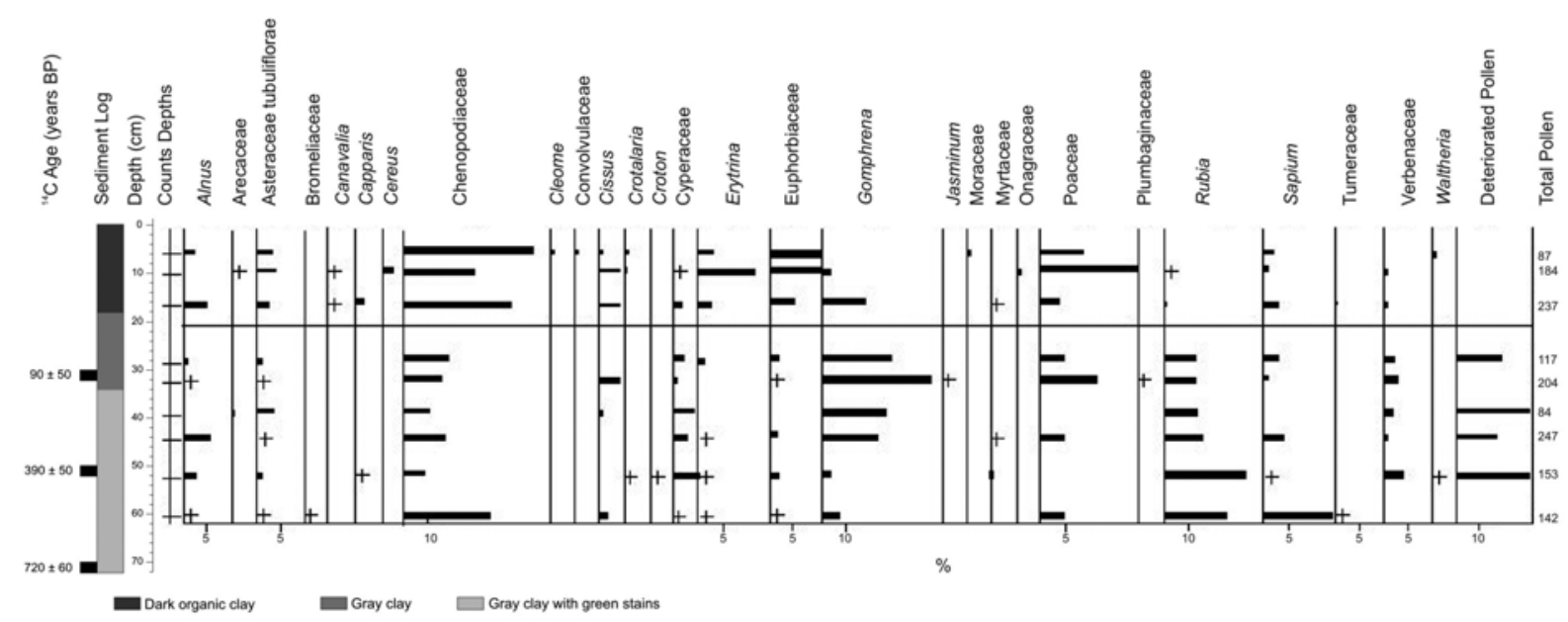

Fig. 4 - Pollen percentage diagram of Lagoa da Viração showing selected taxa. The pollen sum includes arboreal and non-arboreal pollen taxa. Values smaller than $1 \%$ are represented by the "+" sign.

lation to the mineralogy of the soil from the trench located upslope, mainly for the layer $(70-32 \mathrm{~cm})$, indicate that probably this material is a rock alteration material produced in relatively confined environment (Oliveira et al. 2005).

The total $\mathrm{C}$ results showed very low values between $0.32 \%$ and $0.63 \%$ in the deeper layer $(70-32 \mathrm{~cm})$ and an increase in the carbon content reaching values as high as $\sim 17 \%$ is observed in the shallow layer (Fig. 3a). The values of the $\mathrm{C} / \mathrm{N}$ ratio varied from 10.7 at the deeper layer to $\sim 8$ at $32-30 \mathrm{~cm}$, characterizing a predominance of aquatic plants, probably algae in the organic matter of the sediment. Then, a trend to higher values reaching 16.3 is observed in the shallow part of the sediments (Fig. 3b). This gradual increase from $\sim 8$ to $\sim 16 \%$ and the increase in carbon content is probably due to a more significant contribution of organic material from $\mathrm{C}_{3}$ plants (Pistia stratiotes) in the sedimentation of the lake during the recent history of the lake. The contribution of a more recent organic carbon source to the sediments is also observed in the $\delta^{13} \mathrm{C}$ profile. The $\delta^{13} \mathrm{C}$ data (Fig. 3c) are characterized by values around $-22.1 \%$ in the interval 70 to $32 \mathrm{~cm}$, and then a trend toward more depleted $\delta^{13} \mathrm{C}$ is observed in the shallow part of the profile reaching values of $\sim-27.6 \%$ in the shallow layer, which is very similar to the $\delta^{13} \mathrm{C}$ value found for the Pistia aquatic plant $(-28.5 \%$ ). The relationship among $\mathrm{C} / \mathrm{N}$ ratio and $\delta^{13} \mathrm{C}$ values also indi- cates a mixture of aquatic plants, algae and $\mathrm{C}_{3}$ plants (Meyers 2003) in the composition of the sedimentary organic matter of the lake core (Fig. 3d). The low organic carbon and the poor preservation of the pollen observed in the lake core indicated the lake was dry during the dry season allowing the oxidation of the organic matter. The recent history is controlled by the influence of Pistia stratiotes, a specie probably introduced by man in the study area.

\section{MANGUEZAL Do SUESTE}

\section{Sediment type, ${ }^{14} \mathrm{C}$ dating, pollen data and mineralogy}

The sediment stratigraphy as well as the AMS ${ }^{14} \mathrm{C}$ data are presented in the Figure 5 and Table III. The sediments are composed of sand mixed with shells in the deeper part of the profile, changing to mainly sand in the interval 170 and $45 \mathrm{~cm}$. Then, a change to organicrich clay is observed in the shallow part of the profile. This pattern is indicative of depositional changes from a high energy to a low energy environment. ${ }^{14} \mathrm{C}$ ages of $4240 \pm 60 \mathrm{BP}$ and $\sim 2000 \pm 50 \mathrm{BP}$ were obtained in the base of the core (at 216-214 cm) and in the depth of $192-191 \mathrm{~cm}$. The ${ }^{14} \mathrm{C}$ ages obtained for the layers 140 $138 \mathrm{~cm}$ and $132-130 \mathrm{~cm}$ (organic sandy material) were $710 \pm 50 \mathrm{BP}$ and $440 \pm 50 \mathrm{BP}$, respectively. These results indicated a modern age for the sediments composed of organic rich clays between $46 \mathrm{~cm}$ and the surface. 


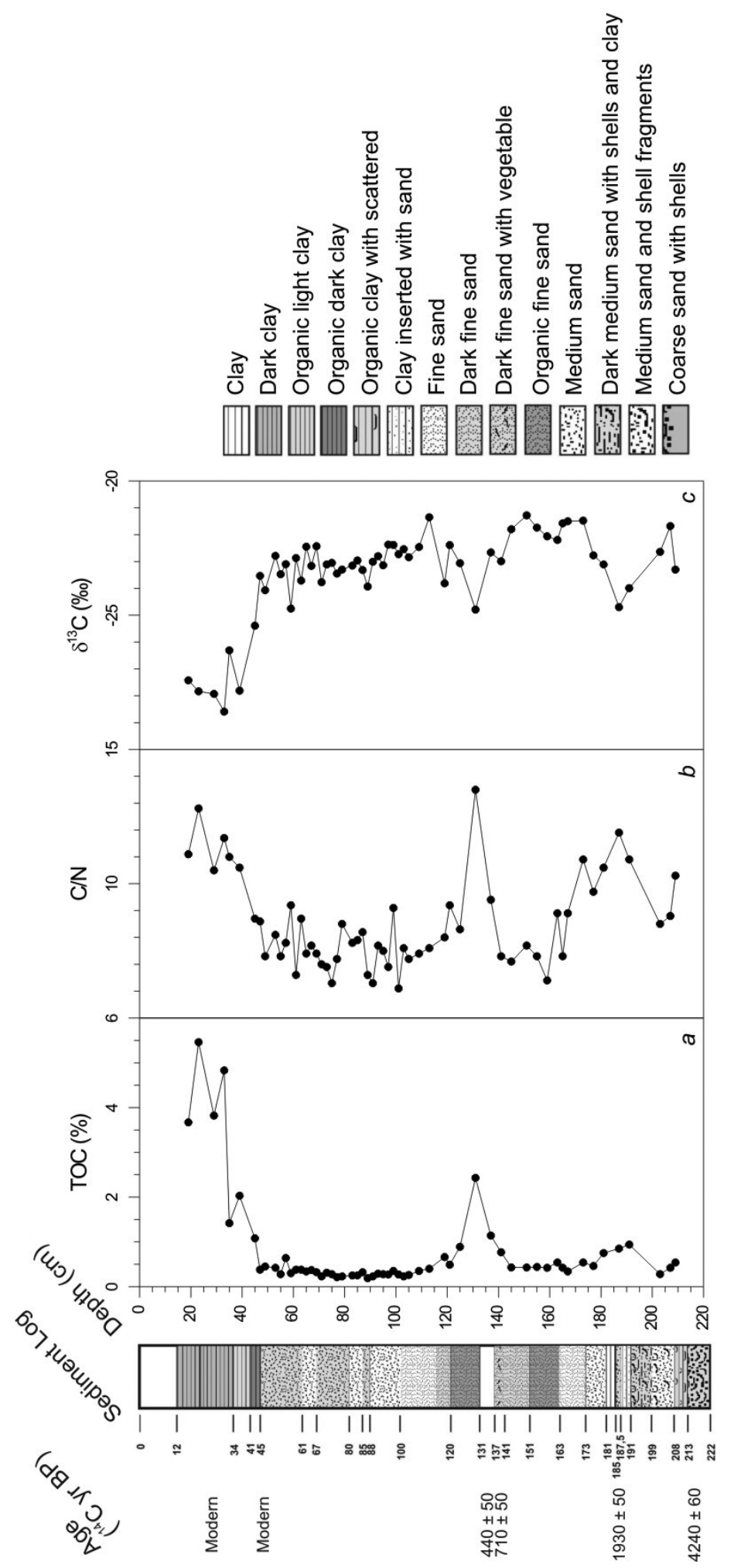

Fig. 5 - Sediment $\log ,{ }^{14} \mathrm{C}$ dating, (a) total organic carbon, (b) $\mathrm{C} / \mathrm{N}$ ratio and (c) $\delta^{13} \mathrm{C}$ values of sediment samples collected in the Manguezal do Sueste. 
Three levels, 191-192 cm, 22-24 cm and 10-12 cm, presented sufficient amount of pollen $(>250)$ for more detailed pollen analysis (Table II, Fig. 6).

In addition to the identified pollen taxa, well-preserved and abundant fragments of cuticles, spores of fungi, algae, some dinoflagellates cysts were found. Folded and fragmented pollens, probably evidencing transport were also found and in the interval 122 $124 \mathrm{~cm}$; an organic foraminifer test was also identified. A total of 52 pollen types belonging to 21 angiosperms families and one gymnosperm (Ephedraceae) were identified (F. Ricardi-Branco, personal communication, Pessenda et al. 2005b).

In spite of the shortage of pollen in most of the studied levels, it was possible to have a general idea about the dynamics of the vegetation. The studied samples were divided in two time intervals: $\sim 2000-440 \mathrm{BP}$ and $440 \mathrm{BP}$ to the present. In the interval $222 \mathrm{~cm}$ (4240 BP) up to $194 \mathrm{~cm}(>2000 \mathrm{BP})$ the sediment material was constituted of thick and medium sand with shells, probably indicating that the current place of the mangrove was a beach. In such case, the sea level probably was above the present level and the mangrove located more into the interior of the island. A significant increase in the sea level reached a maximum at $\sim 5460 \mathrm{cal}$ BP in the central Brazilian coast (Suguio 1993) and a relatively rapid sea level rise occurred at $\sim 5000 \mathrm{cal}$ BP to $\sim 4 \mathrm{~m}$ and induced an overall coastal retreat in the region of Rio Grande do Norte State, northeasthern Brazil. Sea level fell immediately and eventually rose again about 2100-1100 cal BP, resulting in a second coastal retreat in the Holocene (Bezerra et al. 2003). These events can be connected with the dynamic observed for the Manguezal do Sueste around 4240 BP (4780-4970 cal BP) and 1930 BP (1770-1990 cal BP).

Interval $\sim 2000-440$ BP. Pollen of the families Alismataceae, Cyperaceae, Amaranthaceae, Amaranthaceae/ Chenopodiaceae and Araceae were found in the interval 198-196 cm representing an age $>2000$ BP. These pollen can be considered as belonging to the vegetation that inhabited the surroundings of the mangrove. It was also identified pollens of Convolvulaceae (Evolvus and Ipomea), Euphorbiaceae (Sapium and Euphorbia), Moraceae (Ficus), and Combretaceae (Laguncularia), associated to modern vegetation found in Noronha, not introduced with the colonization, and indicating the presence of the mangrove in the same place on that time. In the following interval $(192-191 \mathrm{~cm})$ it was found the same families than the previous interval and the first registration of Arecaceae and Ephedaraceae, possibly transported by the wind or by the Maceió River.

In the interval $186-180 \mathrm{~cm}$, a decreasing in the number of pollen taxa was observed, being registered the families Alismataceae, Amaranthaceae/Chenopodiaceae, Cyperaceae, Poaceae and the absence of pollens of Laguncularia, possibly due to the diminishing of mangrove area, probably associated with the sea-level rise observed in the Rio Grande do Norte coast during the period 2100-1100 cal BP (Bezerra et al. 2003), although were registered for the first time pollen of the families Bombacaceae and Fabaceae (Erythrina).

Interval 440 BP-Present. Pollen of Amaranthaceae/ Chenopodiaceae, Araceae, Convolvulaceae (Ipomea), Cyperaceae, Moraceae (Ficus) and Poaceae were found in the interval 132-130 cm. Pollen of Amaranthaceae/ Chenopodiaceae, Araceae, Convolvulaceae (Ipomea), Cyperaceae, Euphorbiaceae (Euphorbia), Moraceae (Ficus) and Poaceae and the first appearance of Capparaceae (Cleome), Rubiaceae, Malvaceae and the genus Jatropa (Euphorbiaceae) were found in the interval 128$126 \mathrm{~cm}$. As in the previous level, pollen of Laguncularia were not registered. In the sample collected in the interval $124-122 \mathrm{~cm}$ were found only 8 pollens of Poaceae. In the intervals $46-44 \mathrm{~cm}, 34-32 \mathrm{~cm}$ and 24 $22 \mathrm{~cm}$ (modern history) were found the families registered in the previous layers, the reappearance of Laguncularia and for the first time registered pollens of Cassia (Caessalpinaceae), Tabebuia (Bignoniaceae), Leucaena and Desmonthus (Mimosaceae), Ludwigia (Onagraceae), Cupania (Sapindaceae), Walteria (Sterculaceae), Solanaceae, Nyctagina (Nyctaginaceae), Malvaceae, Jasminum (Oleaceae), Verbenaceae and of the genera Desmodium, Crotalaria and Andiroba (Fabaceae) and Capparis (Capparaceae). Considering the presence of these pollens, it is possible to deduce that the mangrove was located in its current position.

The pollen data obtained from the Manguezal do Sueste indicated that numerous species were introduced in the last 400 years, although still representatives of the original flora can be found. The palynomorphs short- 


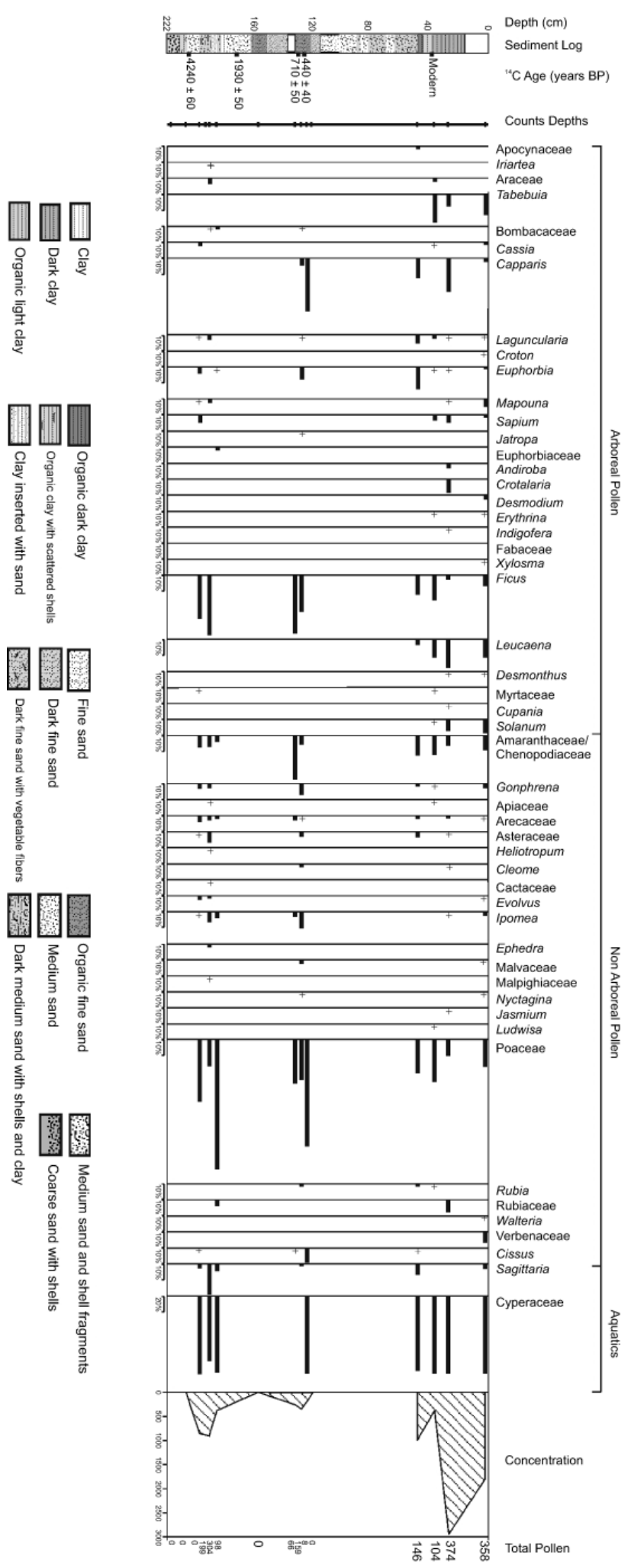

Fig. 6 - Pollen percentage diagram of Manguezal do Sueste showing selected taxa. The pollen sum includes arboreal and non-arboreal pollen taxa. Values smaller than $1 \%$ are represented by the "+" sign. 
age in most of the studied layers can be explained by the influence of several factors such as: direction of the winds, reduced area of the island, poor flora and oscillations in the dimensions of the mangrove, connected with variations in the sea level, probably associated to more arid phases. During these dry periods, the Maceió River is the main source of pollen transportation from the island flora for the mangrove, it might have dried. However, an additional cause of the lower pollen is related to the high energy of deposition linked to the Maceió River, which was the main source of water to the mangrove for most part of his history.

\section{Isotopic and geochemistry data}

For most of the record, the organic carbon content (Fig. $5 a)$ is very low with values less than $1 \%$. A similar pattern is observed in the $\mathrm{C} / \mathrm{N}$ ratios (Fig. $5 \mathrm{~b}$ ), that is characterized by values lower than 10 . The $\delta^{13} \mathrm{C}$ profile (Fig. 5c) also showed most of the $\delta^{13} \mathrm{C}$ values are around $-22 \%$. There are some exceptions below $45 \mathrm{~cm}$ where the $\mathrm{C}$ and $\mathrm{C} / \mathrm{N}$ ratios tend to increase and the $\delta^{13} \mathrm{C}$ values tend to decrease. For example, in the depth interval 138$136 \mathrm{~cm}(\sim 600 \mathrm{BP})$ to $134-132 \mathrm{~cm}(\sim 400 \mathrm{~cm})$, there is an increasing in the concentration of total organic $\mathrm{C}$ (1.14\% to $2.43 \%)$, in the $\mathrm{C} / \mathrm{N}$ ratio $(9.4$ to 13.5$)$ and an isotopic depletion ( $-22.7 \%$ to $-24.8 \%$ ), probably indicating a significant input of organic material of $\mathrm{C}_{3}$ plant origin probably from an external source. Considering the small number of pollens (Table II) and the identified species in the layer $132-130 \mathrm{~cm}$, for this period there is no indication of the presence of a mangrove at the site. The greater changes are observed on the more recent part of the profile where a significant increase in the carbon content and $\mathrm{C} / \mathrm{N}$ ratios and a depletion of the $\delta^{13} \mathrm{C}$ values from $-23.5 \%$ to $-27.8 \%$ are documented. These patterns are accompanied by a change in the lithology from high energy sediments (sand) to low energy sediments (dark organic clay). The pollen analyses in the recent sediments correspond to the modern mangrove vegetation at the site (Table II). The trend of increasing $\mathrm{C} / \mathrm{N}$ and decreasing $\delta^{13} \mathrm{C}$ values indicates an input of organic matter of different origin probably from the mangrove trees that are $\mathrm{C}_{3}$ type plants (Meyers 2003).

The variations observed in the different proxies used in the study probably are associated with climatic events and considering the last hundreds of years, with anthropogenic aspects, in addition to sea level oscillations. The influence of the sea level changes is observed in the sediments rich in shells deposited at the site at least 4500 years ago. The presence of the sand units reflect the influence of the river and the organic rich clay are linked to the construction of a river dam that reduced the input of water from the river watershed. The lack of pollen in most of the record could be also related to oxidation during the river low flow condition during the dry season.

\section{CONCLUSIONS}

Based on results obtained in the soils of Fernando de Noronha and in the record of Lagoa da Viração and Manguezal do Sueste it was concluded that:

1. The climate changes that occurred during the Holocene in the northeastern region of Brazil did not affect significantly the vegetation cover in distinct locations in the Fernando de Noronha Island during the Holocene. This pattern could be associated to the moderate effect of the ocean on the climate of the island.

2. The material of the lower part $(72-60 \mathrm{~cm})$ of the sediment core collected at Lagoa da Viração is probably a rock alteration product in a relatively confined environment. The material of the lower part (72$32 \mathrm{~cm}$ ) of the sediments in the Lagoa da Viração was exposed to the air due to evaporation during the dry season. In the upper part (from $\sim 18 \mathrm{~cm}$ to the surface) it was observed the presence of pollen associated with modern plant species located around the lake regularly deposited and well preserved in the sediment due to the presence of the Pistia stratiotes, a $\mathrm{C}_{3}$ plant that colonized the lake during the last decades due to reduced evaporation during the dry season.

3. The lithology of the sediment collected in the Manguezal do Sueste showed the presence of sand rich in shells associated to sea level changes during the middle and late Holocene ( $\sim 200 \mathrm{BP}$ and $\sim 2000$ BP). The sand and clay deposits represent high and low energy deposition environments. The 
deposition of the organic clays is clearly linked to the construction of a dam in the river watershed during the last decades.

4. Well-preserved pollen representing the present watershed and mangrove vegetation were only found in the recent part of the sediments record. Similarly to the Lagoa da Viração, the poor preservation of the pollen was probably due to oxidation during the dry season.

5. The $\delta^{13} \mathrm{C}$ and $\mathrm{C} / \mathrm{N}$ patterns at both sites showed the input of modern organic matter in the recent part of their history, associated to the presence of Pistia stratiotes in case of Lagoa da Viração, and input from the mangrove vegetation, in case of the Manguezal do Sueste.

\section{ACKNOWLEDGMENTS}

To Fundação de Amparo à Pesquisa do Estado de São Paulo (FAPESP) (01/13262-6, 01/10828-9) for financial support, to IBAMA for administrative support and to M.V.L. Cruz from the ${ }^{14} \mathrm{C}$ Laboratory of Centro de Energia Nuclear/Universidade de São Paulo (CENA/USP) for support during the analyses.

\section{RESUMO}

Esta pesquisa teve o objetivo de reconstruir trocas de vegetação (com referências climáticas) que ocorreram durante o Holoceno na ilha de Fernando de Noronha, Estado de Pernambuco, nordeste do Brasil. Para o desenvolvimento da pesquisa utilizou-se de análises geoquímicas (minerais, elementar), isótopos do carbono $\left(\delta^{13} \mathrm{C},{ }^{14} \mathrm{C}\right)$ e análises polínicas em solos e sedimentos coletados na Lagoa da Viração e no manguezal do Sueste. Os isótopos do carbono dos solos indicaram que não houve trocas significativas de vegetação durante os últimos 7400 anos AP, sugerindo que o clima não foi um fator determinante para a dinâmica da vegetação. A análise polínica dos sedimentos da Lagoa da Viração mostrou ausência de elementos quaternários no período entre 720 AP e 90 AP. A análise mineralógica das camadas mais profundas mostrou a presença de diopsídeo, indicando que este material foi desenvolvido "in situ". Somente na parte superficial do testemunho foram encontrados palinomorfos de plantas similares à vegetação moderna. Os resultados geoquímicos e isotópicos, em associação com o tipo de sedimento e as análises polínicas das amostras de sedimento do Manguezal do Sueste, indicaram variações na vegetação e na sua localização desde o Holoceno médio. Tais variações podem estar associadas a eventos climáticos e oscilações do nível do mar e também a eventos antrópicos considerando os últimos quinhentos anos.

Palavras-chave: pólen, isótopos do carbono, paleovegetação, Fernando de Noronha, Holoceno.

\section{REFERENCES}

Behling H, Arz HW, PÄtzold J And Wefer G. 2000. Late Quaternary vegetation and climate dynamics in northeastern Brazil. Inferences from marine core GeoB 3104-1. Quat Sci Rev 19: 981-994.

BEZERra FHR, BARreto AMF AND Suguio K. 2003. Holocene sea-level history on the Rio Grande do Norte State coast, Brazil. Mar Geol 196: 73-89.

BROWER JE AND ZAR JH. 1984. Field and laboratory methods for general ecology, $2^{\text {nd }}$ ed., Dubuque: W.M.C. Brown Publishers, $226 \mathrm{p}$.

De Oliveira Pe, Barreto AMF And Suguio K. 1999. Late Pleistocene/Holocene climatic and vegetational history of the Brazilian caatinga: the fossil dunes of the middle São Francisco River. Paleogeogr Paleoclimatol Paleoecol 152: 319-337.

FAEGRI K AND IVERSEN J. 1989. Textbook of pollen analysis, $4^{\text {th }}$ ed., J. Wiley $\&$ Sons, Chichester.

Gouveia SEM, Pessenda LCR, Aravena R, Boulet R, SCHEEl-YBert R, BENDASSOLI JA, Ribeiro AS AND FREITAS HA. 2002. Carbon isotopes in charcoal and soils in studies of paleovegetation and climate changes during the late Pleistocene and the Holocene in the southeast and centerwest regions of Brazil. Glob Planet Change 33: 95-106.

Gouveia SEM ET AL. 2005. Estudo multi/interdisciplinar em Fernando de Noronha (PE). In: X CONGRESSO DA ASSOCIAÇÃo BRASILEIRA DE ESTUdOS DO QUATERNÁRIO. Qual a chave para o futuro? Guarapari.

IBAMA. 2005. Disponível na internet no endereço: http://www2.ibama.gov.br/unidades/parques/reuc/31.htm.

KIEHL EJ. 1979. Manual de edafologia; relações solo/planta. São Paulo: Ceres.

Ledru MP, Cordeiro RC, Dominguez JML, Martin L, Mourguiart P, Sifeddine A and Turce B. 2001. Late-glacial cooling in Amazonia inferred from pollen at Lagoa do Caçó, Northern Brazil. Quat Res 55: $47-56$. 
MARTIN L AND FLEXOR JM. 1989. Vibro-testemunhador leve: construção, utilização e possibilidades. In: II CONGRESSO DA ASSOCIAÇÃo BRASILEIRA DE Estudos do QuATERnÁrio, 2, Rio DE JANeiro. São Paulo ABEQUA (Publicação Especial, 1).

MEYERS PA. 2003. Applications of organic geochemistry to paleolimnological reconstructions: a summary of examples from the Laurentian Great Lakes. Org Geochem 34: 261-289.

Oliveira SMB, FaVAro DIT, PESSENdA LCR, Gouveia SEM, SifEddine A, MENOR E AND CORdeIRo RC. 2005. O material de preenchimento da Lagoa da Viração em Fernando de Noronha. In: X CONGResso Brasileiro de Geoquímica. Porto de Galinhas, PE, Brasil.

Pessenda LCR, Aravena R, Melfi AJ And Boulet R. 1996. The use of carbon isotopes $(\mathrm{C}-13, \mathrm{C}-14)$ in soil to evaluate vegetation changes during the Holocene in central Brazil. Radiocarbon 38: 191-201.

Pessenda LCR, Gouveia SEM and Aravena R. 2001. Radiocarbon dating of soil organic matter and humin fraction and its comparison with ${ }^{14} \mathrm{C}$ ages of fossil charcoal. Radiocarbon 43(2B): 595-601.

Pessenda LCR, Ribeiro AS, Gouveia SEM, Aravena R, Boulet R And Bendassoli JA. 2004. Vegetation dynamics during the Late Pleistocene in the Barreirinhas region, Maranhão state, northeastern Brazil, based on carbon isotopes in soil organic matter. Quat Res 62: 183-193.

Pessenda LCR, Ledru MP, Gouveia SEM, AraVena R, Ribeiro AS, Bendassoli JA AND Boulet R. 2005a. Holocene palaeoenvironmental reconstruction in northeastern Brazil inferred from pollen, charcoal and carbon isotope records. Holocene 15: 814-822.

PESSENDA LCR ET AL. 2005b. Dinâmica vegetacional e espacial do Mangue do Sueste, Fernando de Noronha (PE), desde o Holoceno médio. In: X Congresso DA AsSOCIAÇÃo BRASILEIRA DE Estudos DO QUATERNÁRIO. Qual a chave para o futuro? Guarapari.
SIFEDDINE A ET AL. 2003. A 21000 cal years paleoclimatic record from Caçó Lake, northern Brazil: evidence from sedimentary and pollen analyses. Paleogeogr Paleoclimatol Paleoecol 189: 25-34.

Sifeddine A, Wirrmann D, Albuquerque ALS, TurcQ B, CORdeIro RC, GURGEL MHC AND ABrÃo JJ. 2004. Bulk composition of sedimentary organic matter used in palaeoenvironmental reconstructions: examples from the tropical belt of South America and Africa. Paleogeogr Paleoclimatol Paleoecol 214: 41-53.

Suguio K. 1993. Holocene relative sea-level changes along the Central Brazilian and Japanese coasts: possible significance of their similarities and differences. An Acad Bras Cienc 65: 271-278.

Suguio K, Martin L, Bittencourt ACSP, Dominguez JML, FLEXor JM AND AZEvedo AEG. 1985. Flutuações do nível relativo do mar durante o Quaternário superior ao longo do litoral brasileiro e sua implicações na sedimentação costeira. Rev Bras Geocienc 15(4): 273286.

Stuiver M, Reimer P And Braziumas TF. 1998. Highprecision radiocarbon age calibration for terrestrial and marine samples. Radiocarbon 40: 1127-1151.

Teixeira W, Cordani UG, Menor EA, Teixeira MG AND Linsker R. 2003. Arquipélago de Fernando de Noronha. O paraíso do Vulcão. Tempos do Brasil. São Paulo: Terra Virgem Editora, 167 p.

Ulbrich MNC, MARQues LS AND Lopes RP. 2004. As ilhas vulcânicas brasileiras: Fernando de Noronha e Trindade. In: Geologia do Continente Sul-AmeriCANO: Evolução da obra de Fernando Flávio Marques de Almeida, Editora Becca, p. 554-571. 